\title{
Determinants of SMEs Performance in Nigeria: A Pilot Study
}

\author{
Ibrahim Murtala Aminu \\ College of Business, Universiti Utara Malaysia, 06010 Sintok, Malaysia \\ Email: murtalaaminuibrahim@gmail.com \\ Mohd Noor Mohd Shariff
}

College of Business, Universiti Utara Malaysia, Sintok, Malaysia

\section{Doi:10.5901/mjss.2015.v6n1p156}

\begin{abstract}
The objective of this research work is to examine and explore quantitatively a small sample of data on the determinants of SMEs Performance in Nigeria. The study adopted survey approach to collect 46 usable questionnaires from SMEs in Kano as one of the strata based on stratified random sampling method. The model produces six factors that are used as a determinant of SMEs performance in Nigeria. Therefore, validity and reliability of the instruments were examined through panel of expert and also the small sample of the data was analyzed using SPSS v18. Results confirmed the validity and reliability of the instruments adapted in the pilot study.
\end{abstract}

Keywords: SMEs, Nigeria, Performance, Pilot test

\section{Introduction}

The term performance is not new in all aspects of strategic management and management field at large. For example, performance management, performance measurement, performance assessment, or performance evaluation are used in various field of management science. However, the meaning of the word is still relative, there may be no one accepted definition of performance rather it depends on the area and the person defining it. In numerous small business literatures, SMEs performance has been studied by a number of researchers. Most of these studies concentrated on examining causes of SMEs performance, in which quite a lot of variables were recognized as the factors influencing SMEs performance. SMEs performance can be seen as how the firm provides value to its stakeholders such as owners, customers, society and even government. In other words, it indicates how thriving the management manages the firm resources (Moullin, 2007). Neely et al. (1995) defined firm performance as the procedures of quantifying business firm actions of in terms of accomplishing its objectives. Firms attain their objective if they succeed in satisfying their stakeholders' needs more than their rivals. Firm performance can be measured either by looking at economic variables or non-economic variables (Leitao \& Franco, 2008). In other words, it can be measured quantitatively or qualitatively (Augustine, Bhasi, \& Madhu, 2012).

Several studies on firm performance use various organizational resources to measure SMEs performance. Fornoni et al, (2012) in their study use on social capital as antecedents of firm performance. Similarly, in studying SMEs performance short term debt, long term and total debt was used (Ahmad, Abdullah, \& Roslan, 2012). In the same way, AlSwidi and Mahmood (2012) moderated the effect of total quality management, entrepreneurial orientation to study organizational performance. Also, Augustine et al. (2012) studied forecasting, planning, controlling, learning, training, IT usage, age, experience and education of the key person as factors influencing firm performance.

However, studies have shown that entrepreneurial orientation determine performance (Fatoki, 2012; Lechner \& Gudmundsson, 2012; Mutlu \& Aksoy, 2014; Polat \& Mutlu, 2012; Tang \& Tang, 2012). Likewise, quite a lot of studies used market orientation to examine firm performance (Charles, Joel, \& Samwel, 2012; Huhtala, Sihvonen, Frösén, Jaakkola, \& Tikkanen, 2014; Polat \& Mutlu, 2012; Suliyanto \& Rahab, 2012; Wang, Chen, \& Chen, 2012).

Equally, several studies consider learning orientation as variable that influence SMEs performance though (Farrell, Oczkowski, \& Kharabsheh, 2008; Hakala, 2013; Martinette \& Obenchain-Leeson, 2012; Mavondo, Chimhanzi, \& Stewart, 2005; Nybakk, 2012; Suliyanto \& Rahab, 2012). A number of studies used technology orientation in investigating firm performance (Hakala \& Kohtamäki, 2011; Hortinha, Lages, \& Lages, 2011; Voss \& Voss, 2000).

In addition, Mazanai and Fatoki (2012) reveal that access to finance is directly related to the performance of SMEs. 
Thus, the lack of finance adversely affects the full potential of SMEs as an economic driver. Batra, Kaufmann and Stone (2003) state that access to finance allows firms to grow and develop. As SMEs are not operating in a vacuum, a favorable business environment and healthy overall economic setting as a whole are good predictors of performance (Huang \& Brown, 1999; Smit \& Watkins, 2012). According to SMEDAN (2012), unfavorable business conditions and other environmental factors are other issues affecting SMEs' development and performance.

However, most of the studies on strategic orientation adapted entrepreneurial orientation, market orientation, learning orientation and technology orientation measure from Baker and Sinkula (1999); Covin and Slevin (1989); Kohli and Jaworski (1990); Lumpkin and Dess (1996); Narver and Slater (1993). Investigating the reliability and validity of the construct in different environments, economies and context at large before conducting the main survey is needed to ensure the content validity and internal consistency of the measures.

A pilot test was conducted in this study because of two important reasons, firstly, to test the validity and reliability of the survey instruments. Secondly to get a glimpse of the real conditions of the impact assessment, which allows the researcher to anticipate potential problems and adjust when embarking on the actual research. Among the primary concerns of the pilot is the validity and reliability of the instrument. According to Sekaran and Bougie (2010) validity measures the extent to which an instrument is measuring what it should be measuring, while the reliability measures the degree to which an instrument is free from error, consistent and stable across various items of the scale. For this purpose, this paper presents the result of the pilot test about determinants of SMEs performance in Nigeria.

\section{Literature Review}

SMEs are very fundamental for economic development of any country. They contribute immensely to the economic and social development. According to the World Bank (2013), SMEs contribute to the creation of employment which reduces regional disparities between urban and rural areas. The fact is that, it is the SMEs that developed and become large corporations. According to the CBN (2003), SMEs contribute to the creation of employment, as it is one of the sectors that provides industrial employment in Nigeria. SMEs utilize local raw materials that do not require high level technology to process, and this provides an effective means of mitigating rural-urban migration and resource utilization. SMEs use simple technology and recycle by-products and waste from large firms as the input for their production processes. SMEs contribute substantially to the national output through the provision of raw material for larger firms' usage. Also, the government generates revenues from the activities of SMEs through various forms of taxes. They also serve as the means for mobilization and utilization of domestic savings and reduce cost of production, which increases efficiency of the sector.

According to the World Bank (2013), SMEs are defined based on the size of the enterprise in terms of the total number of employees and/ or total assets value. SMEs and large firms can be differentiated based on the aforementioned criteria. However, the definition of SMEs can be viewed from different perspectives, depending on the organization or country. Bouri et al. (2011) define medium enterprises as firms with less than 250 employees and having less than €50 million turnover or not more than $€ 43$ million balance sheet total. A small enterprise refers to firms having less than 50 employees, less than €10 million turnover and/or not more than €10 million balance sheet total.

Stork and Esselaar (2006) report several definitions of SMEs based on different African countries. In Ghana, SMEs referred to firm that have six to 99 number of employees and have not more than 2.5 billion Ghana Cedi $(\$)$ of fixed assets (excluding land and buildings). In South Africa, SMEs are defined as distinct and separate business entities, including cooperative enterprises and non-governmental organizations that are self-managed by a single owner or more which includes its branches or subsidiaries, if any. In Cameroon, SMEs are defined as firms that have turnover value of not less than 1 billion Cameroon Franc (cfa), and accrued investments are not more than 500 million cfa, its short-term credit is not more than 200 million cfa and it has at least $5 \%$ owners of the capital and managers are Cameroonians.

In Nigeria SMEs are defined as the firms that employ fewer than 200 employees and have less than 500 million Naira (N) worth of total assets, excluding land and building (SMEDAN, 2012). Specifically, small enterprises refer to SMEs with employees between 10 to 49 and have N5m to less than N50m assets excluding land and building. Firms with employees between 50 to 199 and have N50m to less than N500m assets excluding land and building is referred to as medium enterprises. Therefore, in this study SMEs are defined as firm with fewer than 200 employees.

Currently, performance of SMEs in Nigeria is below expectations. It is argued that the contribution of SMEs in Nigeria to the national GDP is poor for numerous reasons. These include inadequate infrastructure/financial support to businesses operating within the various sectors; limited application of innovation to operations within the segment; and unfavourable competition from foreign goods and services (Bangudu, 2013; Ndumanya, 2013).

Therefore, building effective strategy is central to any firm as it enables it to achieve and maintain a competitive 
advantage. Hence, in order to survive, firms require a combination of various strategies that are appropriate for rapid environmental changes. In the literature on strategy, researchers have used various variables to represent a firm's strategic activities that are referred to as strategic orientations (Weinzimmer, Robin, \& Michel, 2012).

Entrepreneurial orientation is defined as firms' activity that is represented by the behavior of taking risk, being innovative and proactive (Covin \& Slevin, 1991). It referred to as the combination of a firm's innovativeness, proactiveness, and risk taking. Entrepreneurial orientation can be seen as a particular way by which firms relate to opportunities and activities that lead to new business opportunities (Lumpkin \& Dess, 1996). Additionally, entrepreneurial orientation is one of the important resources that influences firm performance (Lumpkin \& Dess, 2001). Several studies have shown that entrepreneurial orientation is one of the strategic orientations that influences firm performance (Alegre \& Chiva, 2009; Al-swidi \& Al-hosam, 2012; Awang, Ahmad, Subari, \& Said Asghar, 2010; Baker \& Sinkula, 2009; Coulthard, 2007; Fatoki, 2012; Frank, Kessler, \& Fink, 2010; Idar \& Mahmood, 2011; Li, Huang, \& Tsai, 2009; Long, 2013; Madhoushi, Sadati, Delavari, Mehdivand, \& Mihandost, 2011; Moorthy et al., 2012; Rauch, Wiklund, Lumpkin, \& Frese, 2009; Tang \& Tang, 2012).

There are different perspectives to market orientation, although all the perspectives put the customer at a center stage. The perspectives also recognize the importance of information, functional coordination, responding to customer and protecting stakeholders' interest (Lafferty \& Hult, 2001). These market orientation perspectives include the decision making perspective. Shapiro (1988) argues that market orientation is a decision making process in a firm with high management commitment to involve all other departments in the firm. It can be viewed from a market intelligence behavior perspective. Kohli and Jaworski (1990) state that market orientation is a firm activity that focuses on market information generation and dissemination and how the departments respond to information.

Market orientation is also seen as the culture of the firm that is most viable and proficient in creating the fundamental behavior for the creation of superior value to customers for continuous higher business performance (Narver \& Slater, 1990). Also, Ruekert (1992) stresses that market orientation is an activity for obtaining information from customers, using the information to develop customer-centered strategies to respond to the customers' needs. Others view market orientation from a customer-orientation perspective. Deshpandé, Farley and Webster (1993) state that it refers to the identification of customer needs that go together with the development of products and services.

Furthermore, several studies have reported different results on the importance of market orientation in influencing the performance of business firms and businesses in general (Agarwal, Erramilli, \& Dev, 2003; Baker \& Sinkula, 2009; Farrell et al., 2008; Haugland, Myrtveit, \& Nygaard, 2007; Idar \& Mahmood, 2011; Jaworski \& Kohli, 1993; Kara, Spillan, \& DeShields Jr., 2005; Kropp, Lindsay, \& Shoham, 2006; Li, Zhao, Tan, \& Liu, 2008; Mahmoud \& Yusif, 2012; Mahmoud, 2011; Moorthy et al., 2012; Narver \& Slater, 1993; Nikoomaram \& Ma'atoofi, 2011; Noble, Sinha, \& Kumar, 2002; Slater \& Narver, 2000).

Slater and Narver (1995) argue that due to the inability of market orientation to predict firm performance, business firms need to be learning oriented if they want to be successful in the long-run. Similar to this argument, Farrell (2000) states that there is a need for business firms to facilitate learning in their firms. This is because learning orientation is a source of competitive advantage. However, Slater and Narver (1995) contend that market-oriented firms must develop learning orientation culture in order to face competition effectively. On the basis of these arguments, a number of studies on the impact of learning orientation on firm performance has been conducted (Alegre \& Chiva, 2009; Baker \& Sinkula, 1999; Farrell et al., 2008; Farrell \& Mavondo, 2004; Hakala, 2011; Hardley \& Mavondo, 2000; Kropp et al., 2006; Lee \& Tsai, 2005; Long, 2013; Suliyanto \& Rahab, 2012).

Technology orientation is a process of creating or improving product differentiation and product design more than the competitors (Wind \& Mahajan, 1997). In other words, technology orientation is a firm's ability and willingness to develop technological mind-set and utilize it in improving or developing products and services (Gatignon \& Xuereb, 1997). It also referred to as the ability of the firm to utilize its technical knowledge to build a new technical solution to satisfy the needs and wants of the market (Gatignon \& Xuereb, 1997; Spanjol, Qualls, \& Rosa, 2011). Rusetski (2011) conceptualizes technology orientation as the ability and willingness of business firms to obtain technical knowledge and use it to improve product development.

Several studies have been conducted on the contribution of technology orientation to firm performance (Gao, Zhou, \& Yim, 2007; Gatignon \& Xuereb, 1997; Hakala \& Kohtamaki, 2010; Hakala \& Kohtamäki, 2011; Hoq, 2009; Hortinha et al., 2011; Mu \& Di Benedetto, 2011; Spanjol et al., 2011; Voss \& Voss, 2000).

Recently, there is emerging acknowledgement that a better access to finance for SMEs can improve their performance, and in turn lead to private and socioeconomic benefits for the nation's economy (Kumar, 2005). Hence, access to critical resources, such as finance, is among the significant and important factors that encourages SMEs' business activities in any economy (Kelley, Singer, \& Herrington, 2012; Xavier, Kelley, Kew, Herrington, \& 
Vorderwülbecke, 2013). Availability of financing can affect the performance of SMEs either positively or negatively. According to Margaritis and Psillaki (2010), superior firm performance is influenced by high level of leverage. On the other hand, high indebtedness can lead to a product market's underperformance (Campello, 2006).

In addition, topics on strategic orientations and firm performance literature refer to the suggestions that firms should consider their business environment. Several studies have associated firm performance with supportive business environment (Awang et al., 2009; Mahmoud, 2011; Polat \& Mutlu, 2012). Business environment is theoretically recognized as a potential moderating variable that can influence strategic orientations and firm performance relationship (Barney, 1991). Awang et al. (2009) stresses that strategic orientations study seems to be incomplete without environmental eventualities affecting the relationship. Similarly, Frank et al. (2010) conclude that strategic orientations are characterized by environment and cultural differences.

\section{Methodology}

This is a pilot study to remove any doubts about the reliability and validity of the instrument, so the final study will incorporate the suggestions obtained from the pilot study and revises the items where necessary. Therefore, survey research design was adapted in this study. The study assessed the opinion of SMEs owner-mangers about the enterprises (Fisher, 2010). Sample in pilot tests are commonly small (Fink, 2003), although it is normal to be increased to about 100 responses (Dillman, 2007). Thus, total of 60 copies of questionnaires were randomly distributed personally. According to Sekaran and Bougie (2010), self-administered questionnaire helps the researcher to create more understanding with the respondents while introducing the survey. It also serves as the way of making clarifications to the respondent instantly, and the response rate can be high since the collection of the questionnaires is immediate.

The study used questionnaire as the method of data collection. Closed-ended questionnaire found to be more appropriate for this study because of the benefits it has over other methods of data collection. These include better and straightforward generation of statistics such as coding, tabulation and analysis (Dawson, 2007). In addition, closed-ended questionnaire is among the reliable data collection instrument widely used. It encourage the respondents to make a choice fast and easy, and is easier for the researcher to code the data for further analysis (Sekaran \& Bougie, 2010).

Additionally, the items of the questionnaire were gauged on seven-point Likert scale. Out of the 60 questionnaires distributed 52 were retuned, and 6 of them had not been correctly filled, so only 46 were used for analysis. Some questionnaires were received after the closing date and accordingly, were excluded from the analysis. However, the response rate was about $86.6 \%$, which was achieved due to the distribution and collection of questionnaires in person. Validity concerns with the evidence that the instrument used in a study is appropriately measuring the intended concept (Hair Jr., Black, Babin, \& Anderson, 2010; Sekaran \& Bougie, 2010). In this study content or face validity was conducted to ensure the validity of the items on the face of it is measuring the intended construct. Also, the study conducted reliability test, however, there are different statistical methods of testing reliability. Cronbach's alpha coefficient is the most common method used by researchers to test reliability (Sekaran \& Bougie, 2010). It shows the degree to which responses of the respondents to all the items are consistent. To this end, this study use SPSS v18 for Windows to test the reliability of the measures.

\section{Result}

\subsection{Validity Test}

Panel of experts and small sample of respondents were asked to give comment and input on the suitability of the adapted items to measure the construct. Experts consulted include senior lecturers, associate professors and professors in the School of Business, Universiti Utara Malaysia and Bayero University Kano Nigeria. Additionally, some Ph.D. students who are acquainted with Nigeria that constitute the context of the study were consulted to test the clarity of the survey instruments. Moreover, the questionnaire was also given to some SMEs owners-managers for their input. Based on these, some items were re-worded/re-phrased correctly to measure the construct and also to be understood by the potential respondents.

\subsection{Reliability Test}

From the result of the reliability test, it has been found that all the measures have high-reliability values ranging from 0.72 to 0.95 . This is in line with the criterion that a Cronbach's alpha coefficient of 0.60 is considered an average reliability, 
while a coefficient of 0.70 or higher indicates that the instrument has a high reliability standard (Hair, et al., 2010; Nunnally, 1978; Sekaran \& Bougie, 2011). Table 3.1 shows the summary of the reliability results. It can be seen that the results of the pilot test show that the Cronbach's alpha values for the respective constructs under investigation are all above 0.70 . Consequently, given the established yardstick of 0.70 , it can be concluded all the constructs are reliable, and therefore there was no need to remove any item.

Table 3.1: Reliability Test

\begin{tabular}{llcc}
\hline & Construct & Number of Items & Cronbach's Alpha \\
\hline 1 & Firm Performance & 6 & 0.84 \\
2 & Entrepreneurial Orientation & 12 & 0.86 \\
3 & Market Orientation & 13 & 0.91 \\
4 & Learning Orientation & 12 & 0.89 \\
5 & Technology Orientation & 11 & 0.95 \\
6 & Access to Finance & 8 & 0.74 \\
7 & Business Environment & 8 & 0.72 \\
& Total & 70 & \\
\hline
\end{tabular}

Furthermore, the descriptive analysis in Table 4.2 reveals that $63.04 \%$ of enterprises are managed by the owner while $36.96 \%$ are managed by the manager. This indicates more than half of the SMEs in are managed by the owners. Additionally, $45.65 \%$ of the enterprises are manufacturing enterprises while $54.35 \%$ are service enterprises. In line with the trend of SMEs in Nigerian about $67.39 \%$ of the enterprises are small while $32.61 \%$ are medium enterprises. Addition to this trend $65.22 \%$ are sole proprietorship, $26.09 \%$ are partnership and $6.52 \%$ and $2.17 \%$ are Limited Liability Company, not publicly and publicly traded respectively. Finally, over $50 \%$ of the enterprises' total estimated assets are below N5 million.

Table 3.2: Summary of Respondents Demography

\begin{tabular}{lcc}
\hline Item & Frequency & Percent \\
\hline Job position in the enterprise & & \\
Owner & 29 & 63.04 \\
Manager & 17 & 36.96 \\
Main line of business in your enterprise & 21 & 45.65 \\
Manufacturing & 25 & 54.35 \\
Services & & \\
Location of Business & 46 & 100.00 \\
Kano & & \\
Years of enterprise been in existence & 19 & 41.30 \\
Less than 5 years & 20 & 43.48 \\
5-10 years & 4 & 8.70 \\
11- 15 years & 3 & 6.52 \\
More than 15 years & & \\
Number of employees & 31 & 67.39 \\
10 to 49 & 15 & 32.61 \\
50 to 199 & & \\
Current ownership/equity type & 30 & 65.22 \\
Sole proprietorship & 12 & 26.09 \\
Partnership & 3 & 6.52 \\
Limited Liability Company, not publicly traded & 1 & 2.17 \\
Limited Liability Company, publicly traded & & \\
Company's estimated total assets & 24 & 52.17 \\
Less than N5m & 11 & 23.91 \\
Between N5 -N50m & 4 & 8.70 \\
Between N51 -500m & 7 & 15.22 \\
Between N501m and above & &
\end{tabular}




\section{Conclusion}

As explained in the introduction, the objective of this study is pre-tests the content/face validity and reliability of the items of current research in preparation for the main study. It can be seen from the results of the pilot test that the Cronbach's alpha values for the respective constructs under investigation are all above 0.70 . Thus, given the recognized threshold of 0.70 it can be concluded the entire construct are reliable, and therefore there was no need to remove any item.

\section{References}

Agarwal, S., Erramilli, M. K., \& Dev, C. S. (2003). Market orientation and performance in service firms: Role of innovation. Journal of Services Marketing, 17(1), 68-82.

Ahmad, Z., Abdullah, N. M. H., \& Roslan, S. (2012). Capital structure effect on firms performance: Focusing on consumers and industrials sectors on Malaysian firms. International Review of Business Research Papers, 8(5), 137-155.

Alegre, J., \& Chiva, R. (2009). Entrepreneurial orientation, organizational learning capability and performance in the ceramic tiles industry (No. 2009-08) (pp. 3-29). SA, Ivie: Instituto Valenciano de Investigaciones Económicas.

Al-swidi, A. K., \& Al-hosam, A. (2012). The effect of entrepreneurial orientation on the organizational performance : A study on the islamic banks in yemen using the partial least squares approach. Arabian Journal of Business and Management Review (OMAN Chapter), 2(1), 73-84.

Al-Swidi, A. K., \& Mahmood, R. (2012). Total quality management, entrepreneurial orientation and organizational performance: The role of organizational culture. African Journal of Business Management, 6(13), 4717-4727.

Augustine, B., Bhasi, M., \& Madhu, G. (2012). Linking SME performance with the use of forecasting planning and control: Empirical findings from Indian firms. European Journal of Scientific Research, 73(1), 86-105.

Awang, A. B., Ahmad, Z. A. B., Subari, K. A. B., \& Said Asghar, A. R. B. (2010). Entrepreneurial orientation among Bumiputera Small and Medium Agro-based Enterprises (BSMAEs) in west Malaysia: Policy implication in Malaysia. International Journal of Business and Management, 5(5), 130-143.

Awang, A., Khalid, S. A., Kassim, K. M., Ismail, M., Zain, R. S., \& Madar, A. R. S. (2009). Entrepreneurial orientation and performance relations of Malaysian Bumiputera SMEs: The impact of some perceived environmental factors. International Journal of Business and Management, 4(9), P84.

Baker, W. E., \& Sinkula, J. M. (1999). Learning orientation, market orientation, and innovation: Integrating and extending models of organizational performance. Journal of Market-Focused Management, 4(4), 295-308.

Baker, W. E., \& Sinkula, J. M. (2009). The complementary effects of market orientation and entrepreneurial orientation on profitability in small businesses. Journal of Small Business Management, 47(4), 443-464.

Bangudu, O. (2013, September 30). Nigeria's operating environment for businesses has been difficult. Perium Times. Lagos. Retrieved from https://www.premiumtimesng.com

Barney, J. (1991). Firm resources and sustained competitive advantage. Journal of Management, 17(1), 99-120.

Batra, G., Kaufmann, D., \& Stone, A. H. W. (2003). Investment climate around the world: Voices of the firms from the world business environment survey (pp. 1-178). Washington DC: World Bank Publications.

Bouri, A., Breii, M., Diop, M., Kempner, R., Klinger, B., \& Stevenson, K. (2011). Report on support to SMEs in developing countries through financial intermediaries (pp. 2-48). Geneva: Dalberg Global Development Advisors 2011.

Campello, M. (2006). Debt financing: Does it boost or hurt firm performance in product markets? Journal of Financial Economics, 82, $135-172$.

CBN. (2003). Overview of government's efforts in the development of SMEs and the emergence of Small and Medium Industries Equity Investment Scheme (SMIEIS). National Summit on SMIEls Organized by the Bankers' Committee and Lagos Chambers of Commerce and Industry. Lagos: Central Bank of Nigeria (CBN).

Charles, L., Joel, C., \& Samwel, K. C. (2012). Market orientation and firm performance in the manufacturing sector in Kenya. European Journal of Business and Management, 4(10), 20-28.

Coulthard, M. (2007). The role of entrepreneurial orientation on firm performance and the potential influence of relational dynamism (No. 18/07) (pp. 1-12). Melbourne: Monash University Faculty of Business and Economics.

Covin, J. G., \& Slevin, D. P. (1989). Strategic management of small firms in hostile and benign environments. Strategic Management Journal, 10(1), 75-87.

Covin, J. G., \& Slevin, D. P. (1991). A conceptual model of entrepreneurship as firm behavior. Entrepreneurship Theory and Practice, 16(1), 7-25.

Dawson, C. (2007). Practical research methods: A user-friendly guide to mastering research techniques and projects (3rd ed., pp. 1193). Oxford: How To Books Ltd.

Deshpandé, R., Farley, J. U., \& Webster, F. E. (1993). Corporate culture, customer orientation, and innovativeness in a Japanese firms: A quadrad analysis. Journal of Marketing, 57(1), 23-37.

Dillman, D. A. (2007). Mail and internet surveys: The tailored design method (2nd ed., Vol. 2, pp. 1-542). New York: John Wiley \& Sons, Inc.

Farrell, M. A., Oczkowski, E., \& Kharabsheh, R. (2008). Market orientation, learning orientation and organisational performance in 
international joint ventures. Asia Pacific Journal of Marketing and Logistics, 20(3), 289-308.

Farrell, M., \& Mavondo, F. T. (2004). The effect of downsizing strategy and reorientation strategy on a learning orientation. Personnel Review, 33(4), 383-402.

Fatoki, O. (2012). The impact of entrepreneurial orientation on access to debt finance and performance of small and medium enterprises in South Africa. Journal of Social Science, 32(2), 121-131.

Fink, A. (2003). The survey handbook (Vol. 1). Thousand Oaks, CA: Sage.

Fisher, C. (2010). Researching and writing a dissertation: A guidebook for business students (3rd ed., pp. 1-436). England: Pearson Education Limited.

Fornoni, M., Arribas, I., \& Vila, J. E. (2012). An entrepreneur's social capital and performance: The role of access to information in the Argentinean case. Journal of Organizational Change Management, 25(5), 682-698.

Frank, H., Kessler, A., \& Fink, M. (2010). Entrepreneurial orientation and business performance-A replication study. Schmalenbach Business Review, 62, 175-198.

Gao, G. Y., Zhou, K. Z., \& Yim, C. K. B. (2007). On what should firms focus in transitional economies? A study of the contingent value of strategic orientations in China. International Journal of Research in Marketing, 24(1), 3-15.

Gatignon, H., \& Xuereb, J.-M. (1997). Strategic orientation of the firm and new product performance. Journal of Marketing Research, $X X X I V, 77-90$.

Hair Jr., J. F., Black, J. W., Babin, B. J., \& Anderson, E. R. (2010). Multivariate Data Analysis (Seventh Ed., pp. 1-758). Edinburgh: Pearson Education Limited.

Hakala, H. (2011). Strategic orientations in management literature: Three approaches to understanding the interaction between market, technology, entrepreneurial and learning orientations. International Journal of Management Reviews, 13(2), 199-217.

Hakala, H. (2013). Entrepreneurial and learning orientation: Effects on growth and profitability in the software sector. Baltic Journal of Management, 8(1), 102-118.

Hakala, H., \& Kohtamaki, M. (2010). The interplay between orientations: Entrepreneurial, technology and customer orientations in software companies. Journal of Enterprising Culture, 18(3), 265-290.

Hakala, H., \& Kohtamäki, M. (2011). Configurations of entrepreneurial, customer and technology orientation: Differences in learning and performance of software companies. International Journal of Entrepreneurial Behaviour \& Research, 17(1), 64-81.

Hardley, F., \& Mavondo, F. (2000). The relationship between learning orientation, market orientation and organisational performance. In Australian \& New Zealand Marketing Academy Conference (ANZMAC) (pp. 1496-1500). Queensland, Australia.

Haugland, S. A., Myrtveit, I., \& Nygaard, A. (2007). Market orientation and performance in the service industry: A data envelopment analysis. Journal of Business Research, 60, 1191-1197.

Hoq, M. (2009). Innovativeness: Its antecedents and impact on SME business performance. International Journal of Business and Management, 4(11), 100-110.

Hortinha, P., Lages, C., \& Lages, L. F. (2011). The Trade-Off Between Customer and Technology Orientations: and Export Performance. Journal of International Marketing, 19(3), 36-58.

Huang, X., \& Brown, A. (1999). An analysis and classification of problems in small business. International Small Business Journal, 18, $73-85$.

Huhtala, J.-P., Sihvonen, A., Frösén, J., Jaakkola, M., \& Tikkanen, H. (2014). Market orientation, innovation capability and business performance. Baltic Journal of Management, 9(2), 134-152.

Idar, R., \& Mahmood, R. (2011). Entrepreneurial and marketing orientation relationship to performance: The SME Perspective. Interdisciplinary Review of Economics and Management, 1(2), 1-8.

Jaworski, B. J., \& Kohli, A. K. (1993). Market orientation: Antecedents and consequences. The Journal of Marketing, 57(3), 53-70.

Kara, A., Spillan, J. E., \& DeShields Jr., O. W. (2005). The effect of a market orientation on business performance: A study of small sized service retailers using MARKOR scale. Journal of Small Business Management, 43(2), 105-118.

Kelley, D. J., Singer, S., \& Herrington, M. (2012). The Global Entrepreneurship Monitor 2011 Global Report (pp. 1-37). Massachusetts.

Kohli, A. K., \& Jaworski, B. J. (1990). Market orientation: The construct, research propositions, and managerial implications. Journal of Marketing, 54(2), 1-18.

Kropp, F., Lindsay, N. J., \& Shoham, A. (2006). Entrepreneurial, market, and learning orientations and international entrepreneurial business venture performance in South African firms. International Marketing Review, 23(5), 504-523.

Kumar, A. (2005). Measuring financial access through users' surveys core concepts, questions and indicators (pp. 1-54). Washington DC and London.

Lafferty, B. A., \& Hult, G. T. M. (2001). A synthesis of contemporary market orientation perspectives. European Journal of Marketing, 35(1/2), 92-109.

Lechner, C., \& Gudmundsson, S. V. (2012). Entrepreneurial orientation, firm strategy and small firm performance. International Small Business Journal.

Lee, T.-S., \& Tsai, H.-J. (2005). The effects of business operation mode on market orientation, learning orientation and innovativeness. Industrial Management \& Data Systems, 105(3), 325-348.

Leitao, J., \& Franco, M. (2008). Individual entrepreneurship capacity and performance of SMEs (No. 8179). Munich Personal RePEc Archive Individual (pp. 1-13). Portugal. Retrieved from http://mpra.ub.uni-muenchen.de/8179/

Li, Y., Zhao, Y., Tan, J., \& Liu, Y. (2008). Moderating effects of entrepreneurial orientation on market orientation performance linkage: Evidence from Chinese small firms. Journal of Small Business Management, 46(1), 113-133. 
Li, Y.-H., Huang, J.-W., \& Tsai, M.-T. (2009). Entrepreneurial orientation and firm performance: The role of knowledge creation process. Industrial Marketing Management, 38(4), 440-449.

Long, H. C. (2013). The relationship among learning orientation, market orientation, entrepreneurial orientation, and firm performance of Vietnam marketing communications firms. Philippine Management Review, 20, 37-46.

Lumpkin, G. T., \& Dess, G. G. (1996). Clarifying the entrepreneurial orientation construct and linking it to performance. Academy of Management Review, 21(1), 135-172.

Lumpkin, G. T., \& Dess, G. G. (2001). Linking two dimensions of entrepreneurial orientation to firm performance: The moderating role of environment and industry life cycle. Journal of Business Venturing, 16(5), 429-451.

Madhoushi, M., Sadati, A., Delavari, H., Mehdivand, M., \& Mihandost, R. (2011). Entrepreneurial orientation and innovation performance: The mediating role of knowledge management. Asian Journal of Business Management, 3(4), 310-316.

Mahmoud, M. A. (2011). Market orientation and business performance among SMEs in Ghana. International Business Research, 4(1), 241-251.

Mahmoud, M. A., \& Yusif, B. (2012). Market orientation, learning orientation, and the performance of nonprofit organisations (NPOs). International Journal of Productivity and Performance Management, 61(6), 624-652.

Margaritis, D., \& Psillaki, M. (2010). Capital structure, equity ownership and firm performance. Journal of Banking and Finance, 34(3), $621-632$

Martinette, L. A., \& Obenchain-Leeson, A. (2012). The relationship between learning orientation and business performance and the moderating effect of competitive advantage: A service organization perspective. Journal of Service Science (JSS), 5(1), 43-58.

Mavondo, F. T., Chimhanzi, J., \& Stewart, J. (2005). Learning orientation and market orientation: Relationship with innovation, human resource practices and performance. European Journal of Marketing, 39(11/12), 1235-1263.

Mazanai, M., \& Fatoki, O. (2012). Access to finance in the SME sector: A South African perspective. Asian Journal of Business Management, 4(1), 58-67.

Moorthy, M. K., Tan, A., Choo, C., Wei, C. S., Ping, J. T. Y., \& Leong, T. K. (2012). A study on factors affecting the performance of SMEs in Malaysia. International Journal of Academic Research in Business and Social Sciences, 2(4), 224-239.

Moullin, M. (2007). Performance measurement definitions: Linking performance measurement and organisational excellence. International Journal of Health Care Quality Assurance, 20(3), 181-183.

Mu, J., \& Di Benedetto, C. A. (2011). Strategic orientations and new product commercialization: Mediator, moderator, and interplay. $R \& D$ Management, 41(4), 337-359.

Mutlu, H. M., \& Aksoy, H. (2014). Strategic orientations, firm capabilities, and export performance: An empirical analysis in Turkey. International Journal of Economic Practices and Theories, 4(2), 214-221.

Narver, J. C., \& Slater, S. F. (1990). The effect of a market orientation on business profitability. Journal of Marketing, 54(4), 20-35.

Narver, J., \& Slater, S. (1993). Market orientation and customer service: The implications for business performance. In W. F. Van Raaji \& G. J. Bamossy (Eds.), European Advances in Consumer Research (1st ed., Vol. 1, pp. 317-321). European Advances in Consumer Research.

Ndumanya, N. (2013). Why SMEs' contribution to the nation's GDP is poor. BusinessDay. Lagos Nigeria.

Neely, A., Gregory, M., \& Platts, K. (1995). Performance measurement system design: A literature review and research agenda. International Journal of Operations \& Production Management, 15(4), 80-116.

Nikoomaram, H., \& Ma'atoofi, A. R. (2011). The effect of learning orientation on market orientation and performance in small sized firms: Evidence from Iran. European Journal of Social Sciences, 18(4), 632-642.

Noble, C. H., Sinha, R. K., \& Kumar, A. (2002). Market orientation and alternative strategic orientations: A longitudinal assessment of performance implications. The Journal of Marketing, 66, 25-39.

Nybakk, E. (2012). Learning orientation, innovativeness and financial performance in traditional manufacturing firms : A higher- order structural equation model. International Journal of Innovation Management, 16(5), 1-34.

Polat, I.., \& Mutlu, H. M. (2012). The impacts of market orientation, entrepreneurial orientation, environmental uncertainty and internationalization speed on firm performance. European Researcher, 27(8-2), 1248-1254.

Rauch, A., Wiklund, J., Lumpkin, G. T., \& Frese, M. (2009). Entrepreneurial orientation and business performance: An assessment of past research and suggestions for the future. Entrepreneurship Theory and Practice, 33(3), 761-787.

Ruekert, R. W. (1992). Developing a market orientation: An organizational strategy perspective. International Journal of Research in Marketing, 9(3), 225-245.

Rusetski, A. (2011). Getting proactive: Cultural and procedural drivers of managerial motivation to act. Journal of Business \& Economics Research (JBER), 9(1).

Sekaran, U., \& Bougie, R. (2010). Research methods for business: A skill building approach (5th ed., pp. 1-387). United Kindom: John Wiley \& Sons Ltd.

Shapiro, B. P. (1988). What the hell is market oriented? (pp. 1-3). Harvard Business Review, Reprint Service.

Slater, S. F., \& Narver, J. C. (1995). Market orientation and the learning organization. The Journal of Marketing, 59(3), 63-74.

Slater, S. F., \& Narver, J. C. (2000). The positive effect of a market orientation on business profitability: A balanced replication. Journal of Business Research, 48(1), 69-73.

SMEDAN. (2012). Survey report on Micro, Small, and Medium Enterprises (MSMEs) in Nigeria. Abuja: Small and Medium Enterprises Development Agency of Nigeria.

Smit, Y., \& Watkins, J. A. (2012). A literature review of small and medium enterprises (SME) risk management practices in South Africa. 
African Journal of Business Management, 6(21), 6324-6330.

Spanjol, J., Qualls, W. J., \& Rosa, J. A. (2011). How many and what kind? The role of strategic orientation in new product ideation. Journal of Product Innovation Management, 28(2), 236-250.

Stork, C., \& Esselaar, S. (2006). Towards an African e-index: SME e-access and usage across 14 African countries (pp. 1-152). Research ICT Africa.

Suliyanto, S., \& Rahab, R. (2012). The role of market orientation and learning orientation in improving innovativeness and performance of small and medium enterprises. Asian Social Science, 8(1), 134-145.

Tang, Z., \& Tang, J. (2012). Entrepreneurial orientation and SME performance in China's changing environment: The moderating effects of strategies. Asia Pacific Journal of Management, 29(2), 409-431.

Voss, G. B., \& Voss, Z. G. (2000). Strategic orientation and firm performance in an artistic environment. The Journal of Marketing, 6783.

Wang, C.-H., Chen, K.-Y., \& Chen, S.-C. (2012). Total quality management, market orientation and hotel performance: The moderating effects of external environmental factors. International Journal of Hospitality Management, 31(1), 119-129.

Weinzimmer, L., Robin, J., \& Michel, E. (2012). The measurement of strategic orientation and its efficacy in predicting financial performance. Journal of Business Strategies, 29(2), 81-98.

Wind, J., \& Mahajan, V. (1997). Issues and opportunities in new product development: An introduction to the special issue. Journal of Marketing Research, XXXIV(1), 1-12.

World Bank. (2013). The little data book on private sector development. World Bank.

Xavier, S. R., Kelley, D., Kew, J., Herrington, M., \& Vorderwülbecke, A. (2013). Global Entrepreneurship Monitor GEM 2012 Global report (pp. 1-87). Massachusetts. 